Research article

\title{
Effects of different nitrogen forms on growth, phenolics, flavonoids and antioxidant activity in amaranth species
}

\author{
Rozy Munene ${ }^{1 *}$, Evans Changamu ${ }^{2}$, Nicholas Korir ${ }^{1}$ and Gweyi-Onyango Joseph ${ }^{1}$ \\ ${ }^{1}$ Department of Agricultural Science and Technology, Kenyatta University, Nairobi, Kenya \\ ${ }^{2}$ Department of Chemistry, Kenyatta University, Nairobi, Kenya
}

*Corresponding Author: rozymunene@gmail.com

[Accepted: 20 February 2017]

\begin{abstract}
Higher plants, accumulate large number of polyphenolic compounds which are believed to act as defence compounds against different environmental constraints. Nitrogen $(\mathrm{N})$ is a critical element for plant growth, absorbed as $\left(\mathrm{NH}_{4}{ }^{+}\right)$and $\left(\mathrm{NO}_{3}{ }^{-}\right)$, which affects plant growth and to some extent contributes to secondary metabolites accumulation. Greenhouse experiment was carried out to determine the effect of $\mathrm{N}$ forms on growth and phytochemical accumulation in Amaranthus species. Two amaranth varieties; AB6 and AB7 constituted the main plot while three $\mathrm{N}$ forms; ammonium, nitrate, ammonium nitrate and control (no $\mathrm{N}$ form) represented the subplot. Destructive sampling was done and plant height was recorded. Folin-Ciocalteu's and aluminium trichloride methods were used to determine total phenolic content (TPC) and total flavonoid content (TFC) respectively. DPPH (diphenylpicrylhydrazyl) radical scavenging activity assay was used to obtain total antioxidant activity. Nitrogen forms significantly $(p \leq 0.05)$ affected plant height between two amaranth varieties. Under nitrate treatment, AB7 exhibited greater height $(40.2 \mathrm{~cm})$ than AB6 $(35.2 \mathrm{~cm})$. Furthermore, $\mathrm{N}$ effect was more evident in AB6 variety, where by compared to the control, $\mathrm{NO}_{3}{ }^{-}$as exclusive $\mathrm{N}$ source enhanced shoot length by $64 \%$ in $\mathrm{AB} 6$ and $51 \%$ in $\mathrm{AB} 7$ which was twice that of the $\mathrm{NH}_{4}{ }^{+}-\mathrm{N}$ treated plants. Sole $\mathrm{NH}_{4}{ }^{+}$and no $\mathrm{N}$ form enhanced accumulation of both TFC and TPC, unlike nitrate and ammonium-nitrate mixture. Compared to $\mathrm{NH}_{4}{ }^{+}$treatment, $\mathrm{NO}_{3}{ }^{-}$reduced TFC by $17.4 \%$ in AB6- variety and $14.7 \%$ in $\mathrm{AB} 7$ variety and TPC accumulation by $23 \%$ AB6 and $20 \%$ AB7 varieties respectively. Correspondingly, $\mathrm{NH}_{4}^{+}-\mathrm{N}$ form resulted to superior antioxidant DPPH scavenging activity indicated by high scavenging activity and lower $\mathrm{IC}_{50}$ value (concentration which scavenged $50 \%$ of the DPPH radicals). Plant height displayed a significant negative correlation with TFC and TPC accumulation of $r=0.75$ and $r=0.81$ respectively. The results indicated that ammonium-induced stress enhanced total flavonoids and phenolics accumulation; a salient phytochemical plasticity observed during plant growth and survival trade-off in a vegetable amaranth.
\end{abstract}

Keywords: Nitrogen forms - Ammonium- Nitrate - Phenolics - Flavonoids - Amaranth.

[Cite as: Munene R, Changamu E, Korir N \& Gweyi-Onyango J (2017) Effects of different nitrogen forms on growth, phenolics, flavonoids and antioxidant activity in amaranth species. Tropical Plant Research 4(1): 8189]

\section{INTRODUCTION}

African indigenous vegetables, including leafy amaranth occupy a very important place in the human diet in African communities and they are believed to have some form of medicinal and therapeutic properties (Mavengahama 2013). They are not only excellent host of numerous vitamins and mineral elements (Kwenin et al. 2011, Habwe et al. 2009) but also reported to contain immense bioactive phytochemical compounds strongly associated with the health and remedial benefits (Amabye 2015). Higher plants portray a considerable metabolic plasticity by increased production and accumulation of myriad phytochemicals such as flavonoid and phenolic compounds, enabling them survive the various biotic and abiotic stresses (Nakabayashi \& Saito 2015, Altiok 2010). As the polyphenolic compounds effects positively on human health because of their antioxidative and 
protective properties, it achieved more interest in the last decade. Several studies have shown that phytochemicals have antibacterial (Amabye 2015), anticancer (Mates et al. 2011); anti-aging attributes (Xiang et al. 2011). Observational epidemiology studies have indicated that significant dietary intake of flavonoids and phenolics are associated with a lower incidence of various cancers (Collins 2005).

Both the primary and secondary metabolism of higher plants is influenced by mineral nutrition (Caretto et al. 2015). Species growing in nutrient-poor habitats often have traits that lead to high nutrient retention and high levels of secondary metabolites (Lillo et al. 2008). Deficiency in mineral elements such phosphorous and potassium have been reported to up-regulate the amounts of polyphenols either as existing pools or by inducing their de novo synthesis (Kovácik et al. 2007, Glynn et al. 2008). Nakabayashi et al. (2014) observed that increased amount of flavonoids as a consequence of phosphorous and water limitation. Drought often causes oxidative stress (Akula \& Ravishankar 2011) and was reported to show increase in the amounts of flavonoids and phenolic acids in Solanum species and Ligustrum vulgare (Okello 2015, Tattin et al. 2004). Phosphorous stress was reported to elevate total phenolic and antioxidant activity in black nightshade (Ogembo 2015).

Nitrogen is a one of the most critical elements affecting plant growth and development (Zhou et al. 2011). Unlike other elements nitrogen is metabolized by plants in two ionic forms $\mathrm{NH}_{4}{ }^{+}$andNO${ }_{3}^{-}\left(\mathrm{Olfati}_{\text {et }}\right.$ al. 2012) which not only affects plant growth but also nutritional quality of higher plants (Sun et al. 2014, Sabir et al. 2013). Nitrogen nutrition is of great importance as it influences both the primary and secondary metabolic pathways thus secondary plant metabolites accumulation (Chen et al. 2011). Deficiency of crucial elements for instance nitrogen has been found to enhance accumulation of phenolics compounds in the plant tissues (Ibrahim et al. 2011). Previous studies (Argyropoulou et al. 2015, Salahas et al. 2011) have demonstrated that different rates of $\mathrm{N}$ application can influence phytochemical buildup in plant tissues; however very little has been done on effects of different $\mathrm{N}$ forms. Therefore the aim of the present study was to evaluate the effects of $\mathrm{N}$ forms on growth and total flavonoids and phenolic concentration in leafy amaranth. The information is relevant in $\mathrm{N}$ forms management for optimum derivation of these vital therapeutic components.

\section{MATERIALS AND METHODS}

\section{Experimental Design and Treatments}

The experiments were laid out in a split plot arrangement on a Randomized Complete Block Design (RBCD) replicated three times. The main plot comprised of two vegetable amaranth varieties i.e. Abukusa 6 (AB6) and Abukusa 7 (AB7) while three $\mathrm{N}$-forms $\left(\mathrm{NO}_{3}{ }^{-}, \mathrm{NH}_{4}{ }^{+}\right.$and $\mathrm{NH}_{4} \mathrm{NO}_{3}$ ) and control (no $\mathrm{N}$ form used) constituted the sub-plots. Sole $\mathrm{NH}_{4}{ }^{+}$and $\mathrm{NH}_{4} \mathrm{NO}_{3}$ were stabilized with padin ${ }^{\circledR}$ as the nitrification inhibitor composed of a mixture of dicyandiamide and 3,4 methylpyrazole phosphate.

\section{Agronomic practices}

Amaranth seeds were obtained from Jomo Kenyatta University of Agriculture and Technology (JKUAT). The seeds were directly sown $2 \mathrm{~kg}$ containers and about two grams of Triple superphosphate (TSP) was used as basal fertilizer. Watering of the amaranth plants was done daily.

\section{Harvesting and Preparation of plant samples}

Harvesting of the plant samples was done by uprooting the whole plant. The shoots and roots were separated and shoot height recorded in centimeter $(\mathrm{cm})$. Plant shoots (stems and leaves) were oven dried at $60-65^{\circ} \mathrm{C}$ for 72 hours until the weight was constant and dry weight recorded. The dried plant samples were groundusing a grinder-MIKA $^{\circledR}$ to fine powder $(0.2 \mathrm{~mm})$ which was kept in zip lock polythene bags, appropriately labeled and stored in the dark awaiting phytochemical analysis.

\section{Extraction of plant material}

About $20 \mathrm{~g}$ of the powdered plant material was weighed, placed in a flask, $100 \mathrm{ml}$ methanol AR was added and allowed to stand for 48-72 hours. It was then filtered through Whatman filter paper No. 1 and distilled using rotary evaporatorat $65^{\circ} \mathrm{C}$ until methanol-free paste was obtained (Mibei et al. 2012). The resulting extracts were properly labeled and preserved at $5^{\circ} \mathrm{C}$ in airtight plastic bottles for further use.

\section{Total flavonoids contents analysis}

The $\mathrm{AlCl}_{3}$ method (Mervat et al. 2009) was used for the determination of total flavonoid content (TFC) of the sample extracts. Portions of $1.5 \mathrm{ml}$ of $1: 10 \mathrm{~g} \cdot \mathrm{ml}^{-1}$ extracts were added to equal volumes of a solution of $2 \%$ $\mathrm{AlCl} 36 \mathrm{H}_{2} \mathrm{O}$. The mixture was vigorously shaken and allowed to stand between 10-15 min. and absorbance read 
with a spectrophotometer (Spectro SC labmed inc.) at $425 \mathrm{~nm}$. Flavonoid contents were expressed as $\mathrm{mg}$ catchin equivalent $\left(\mathrm{mgCE} . \mathrm{g}^{-1}\right)$ dry weight.

\section{Total phenolic contents Analysis}

Total phenolics content (TPC) was determined by Folin Ciocalteu reagent (Esmaeili et al. 2009, Nabavi et al. 2008). Dilute solution of amaranthextracts $\left(0.5 \mathrm{ml} \mathrm{of} 1: 10 \mathrm{~g} \cdot \mathrm{ml}^{-1}\right)$ or gallic acid (standard phenolic compound) was mixed with Folin Ciocalteu reagent ( $5 \mathrm{ml}, 1: 10$ diluted with distilled water) and aqueous 5\% $\mathrm{Na}_{2} \mathrm{CO}_{3}(4 \mathrm{ml})$. The mixture was allowed to stand for 15 minutes and absorbance determined at $765 \mathrm{~nm}$ with a spectrophotometer (Spectro SC labmed Inc.). The standard curve was prepared by 0, 50, 100, 150, 200, and 250 mg.ml. $\mathrm{l}^{-1}$ solutions of gallic acid to determine the total phenolic concentrations. Total phenolic content values are expressed in terms of gallic acid equivalent $\left(\mathrm{mgGAE} \cdot \mathrm{g}^{-1}\right)$ of dry weight.

\section{Anti-oxidant analysis}

Diphenylpicrylhydrazyl (DPPH) was used to determine radical-scavenging capacity of samples according to (Mibei et al. 2012). Different concentrations $0.05,0.1,0.5,1.0,2.0$ and $5 \mathrm{mg}^{-\mathrm{ml}^{-1}}$ of the extracts were prepared, in methanol. One $\mathrm{ml}$ of the extract was placed in a test tube, $3 \mathrm{ml}$ of methanol added followed by $0.5 \mathrm{ml}$ of $1 \mathrm{mM}$ DPPH in methanol. This was shaken vigorously and left to stand for about five minutes. Concentrations of ascorbic acid were prepared at the same concentrations as the extract and used as standard. Blank solution was prepared with same amount of DPPH and methanol. Absorbance of the solutions was obtained at $517 \mathrm{~nm}$ with a spectrophotometer (Spectro SC labmed Inc.). Radical scavenging capacity of the samples determined using formula:

$$
\% \text { inhibition }=\frac{\mathrm{Ab}-\mathrm{Aa}}{\mathrm{Ab}} \times 100
$$

Where, $\mathrm{Ab}=$ absorption of the blank sample; $\mathrm{Aa}=$ absorption of the extract.

\section{Data analysis}

Data was subjected to analysis of variance (ANOVA) at 95\% confidence level using SAS- computer software (SAS 2015, Version 9.0). Where significant, mean separation was obtained by LSD. Data was presented inform of tables and graphs.

\section{RESULTS}

\section{Plant height}

Nitrogen forms significantly $(\mathrm{P} \leq 0.05)$ affected shoot height in the greenhouse experiment (Fig. 1). Data showed that ammonium depressed plant growth (height) for both varieties compared to nitrate as a sole $\mathrm{N}$ source. Variety AB7 had greater height $(40.2 \mathrm{~cm})$ than AB6 $(35.2 \mathrm{~cm})$ under nitrate treatment. Compared to the control, provision of nitrate as sole source of $\mathrm{N}$ enhanced shoot length by $64 \%$ in $\mathrm{AB} 6$ and $51 \%$ in $\mathrm{AB} 7$ which was twice that of the ammonium treated amaranth plants.

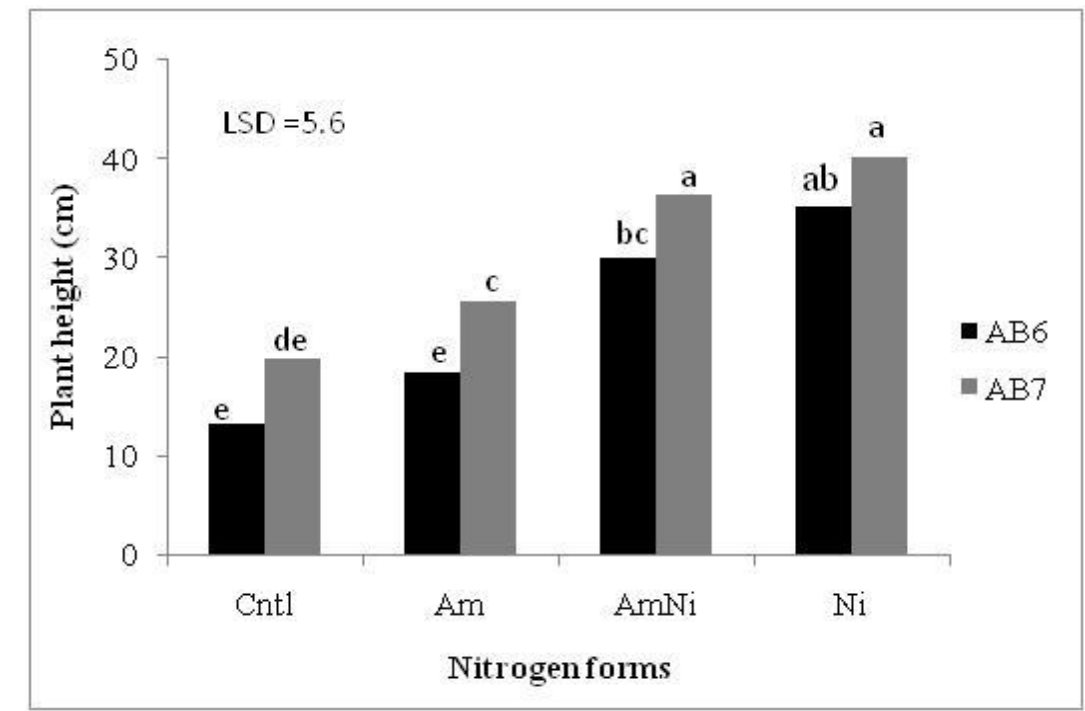

Figure 1. Effects of nitrogen forms on amaranth plant height. 
This plant height was same for both accessions when no $\mathrm{N}$ was supplied but once ammonium was supplied, AB7's performance was statistically superior as compared to control plants. Nitrate treatment led to 2 folds increase in height when compared to control for AB7 variety while the increase was almost 4 folds for AB6. The accession $\mathrm{AB} 7$ grows better than $\mathrm{AB} 6$ but what is significant is that responds better to $\mathrm{N}$ in nitrate and ammonium-nitrate $\mathrm{N}$ source.

\section{Total flavonoids and phenolics concentration}

Nitrogen forms had a significant $(\mathrm{P} \leq 0.05)$ effect on the total shoot flavonoids and phenolics content. The results revealed a stimulatory effect of sole ammonium on shoot TFC and TPC accumulation in amaranth plants. Compared to nitrate, ammonium increased TFC by 17.4\% in AB6 and 14.7\% in AB7. Ammonium increased TPC by $23 \%$ in AB6 and $20 \%$ in AB7 as opposed to when nitrate was added as N source. Amaranth plants not treated with $\mathrm{N}$ form (control) had comparatively higher TFC to ammonium form while accumulation of TPC in the plants treated with ammonium form was statistically at par with the control for AB6 variety (Table 1).

\begin{tabular}{|c|c|c|c|}
\hline \multicolumn{2}{|c|}{ Treatments } & $\begin{array}{l}\text { Total flavonoids } \\
\text { Contents (mg.g }{ }^{-1} \text { GAE) }\end{array}$ & $\begin{array}{l}\text { Total phenolics contents } \\
\left(\mathrm{mg.g} \mathrm{g}^{-1} \text { GAE) }\right.\end{array}$ \\
\hline \multirow[t]{4}{*}{ AB6 } & Cntl & $28.2^{\mathrm{b}}$ & $72.6^{\mathrm{b}}$ \\
\hline & Am & $25.2^{\mathrm{d}}$ & $75.5^{\mathrm{b}}$ \\
\hline & $\mathrm{AmNi}$ & $23.1^{\mathrm{e}}$ & $61.4^{\mathrm{d}}$ \\
\hline & $\mathbf{N i}$ & $20.8^{\mathrm{f}}$ & $58.1^{\mathrm{e}}$ \\
\hline \multirow[t]{4}{*}{ AB7 } & Cntl & $30.6^{\mathrm{a}}$ & $74.7^{\mathrm{b}}$ \\
\hline & Am & $26.7^{\mathrm{c}}$ & $79.9^{\mathrm{a}}$ \\
\hline & AmNi & $23.0^{\mathrm{e}}$ & $64.2^{\mathrm{d}}$ \\
\hline & $\mathbf{N i}$ & $22.8^{\mathrm{e}}$ & $63.9^{\mathrm{d}}$ \\
\hline \multirow{2}{*}{\multicolumn{2}{|c|}{$\begin{array}{l}\text { P value } \\
\text { LSD }\end{array}$}} & 0.001 & 0.001 \\
\hline & & 1.1 & 3.0 \\
\hline \multicolumn{2}{|c|}{$\mathbf{N} \times \mathbf{V}$} & $*$ & NS \\
\hline
\end{tabular}

Interesting, AB7 was still superior to AB6 variety (Fig. 1 and Table 1). Though the ammonium treatment elicited greater accumulation of TFC and TPC, AB7 was superior. Naturally it would be expected that production of these phytochemicals incur some energy costs and hence the variety accumulating less should grow slowly (shorter).

\section{Antioxidant DPPH Radical-Scavenging Activity}

The $\mathrm{IC}_{50}$ (concentration which scavenged $50 \%$ of the DPPH radicals) values of the amaranth extracts ranged from $0.06 \mathrm{mg} \cdot \mathrm{ml}^{-1}$ to $1.80 \mathrm{mg} \cdot \mathrm{ml}^{-1}$. Ammonium as sole $\mathrm{N}$ source had superior antioxidant DPPH scavenging activity indicated by lower $\mathrm{IC}_{50}$ value for $\mathrm{AB} 7\left(0.06 \mathrm{mg} \cdot \mathrm{ml}^{-1}\right.$ and $\mathrm{AB} 6\left(0.3 \mathrm{mg} \cdot \mathrm{ml}^{-1}\right)$ compared to nitrate treatment for AB7 (0.7 mg.ml $\left.{ }^{-1}\right)$ and AB6 (1.8 mg. ml $\left.{ }^{-1}\right)$ (Table 2); an indication of ammonium treated plants to possess great antioxidative capacity as compared to nitrateand ammonium nitrate mixture which require a bit bigger volumes to scavenge $50 \%$ of DPPH radicals.

Table 2. $\mathrm{IC}_{50}$ and maximum percentage inhibition values for the 2 amaranth extracts.

\begin{tabular}{|c|c|c|c|c|c|}
\hline Treatments & & $\begin{array}{l}\mathrm{IC}_{50} \\
\left(\mathrm{mg} \cdot \mathrm{ml}^{-1}\right)\end{array}$ & $\begin{array}{l}\text { Max } \\
(\%)\end{array}$ & Inhibition & $\begin{array}{l}\text { Concentration } \\
\left(\mathrm{mg} \cdot \mathrm{ml}^{-1}\right)\end{array}$ \\
\hline \multirow[t]{4}{*}{$\mathrm{AB} 6$} & Cntl & 0.40 & 82.0 & & 2 \\
\hline & $\mathrm{Am}$ & 0.30 & 72.8 & & 2 \\
\hline & $\mathrm{AmNi}$ & 1.00 & 60.9 & & 5 \\
\hline & $\mathrm{Ni}$ & 1.80 & 65.0 & & 5 \\
\hline \multirow[t]{4}{*}{$\mathrm{AB} 7$} & Cntl & 0.09 & 75.0 & & 2 \\
\hline & $\mathrm{Am}$ & 0.06 & 86.1 & & 1 \\
\hline & $\mathrm{AmNi}$ & 0.60 & 70.1 & & 2 \\
\hline & $\mathrm{Ni}$ & 0.70 & 64.3 & & 5 \\
\hline Ascorbic acid & & 0.07 & 89.5 & & 5 \\
\hline
\end{tabular}

In addition ammonium form extract revealed a remarkable maximum inhibition percentage $72.8 \%$ for $\mathrm{AB} 6$ and $86.1 \%$ for $\mathrm{AB} 7$ at a lower concentration of $2 \mathrm{mg} \cdot \mathrm{ml}^{-1}$ unlike nitrate $(65 \%$ for $\mathrm{AB} 6$ and $64.3 \%$ for $\mathrm{AB} 7)$ and ammonium nitrate mixture $\left(60.9 \%\right.$ for $\mathrm{AB} 6$ and $70.1 \%$ ) which with maximum inhibition of $5 \mathrm{mg} . \mathrm{ml}^{-1}$ which was 2.5 folds higher than that of ammonium. Control had equally superior antioxidant capacity as ammonium 
(Table 2). Maximum inhibition of ascorbic acid (89.5\%) was higher than that of amaranth extract, however at a higher concentration $\left(5 \mathrm{mg} \cdot \mathrm{ml}^{-1}\right)$ than that of ammonium treated amaranths and the control and indication of notable stimulatory antioxidative effect of ammonium form.

\section{Relationshipbetween plant growth and phytochemical accumulation}

Enhancement of TFC and TPC accumulation was observed under reduced plant shoot growth (height) exhibited by negative correlation coefficient $(r=0.75$ and $r=0.81)$ respectively (Table 3 ).

Table 3. Pearson correlations coefficient between measured plant growth parameters and phytochemical accumulation and antioxidant DPPH scavenging activity.

\begin{tabular}{lllllll}
\hline & $\mathbf{1}$ & $\mathbf{2}$ & $\mathbf{3}$ & $\mathbf{4}$ & $\mathbf{5}$ & $\mathbf{6}$ \\
\hline Shoot fresh weight & 1 & & & & & \\
Root fresh weight & $0.75^{* *}$ & 1 & & & & \\
Shoot height & $0.91^{*}$ & $0.86^{*}$ & 1 & & & \\
TFC & $-0.75^{* *}$ & $-0.66^{*}$ & $-0.75^{*}$ & 1 & & \\
TPC & $-0.85^{*}$ & $-0.64^{*}$ & $-0.81^{* *}$ & $0.68^{* *}$ & 1 & \\
Ant. activity & $-0.65^{*}$ & $-0.60^{*}$ & $-0.69^{*}$ & $0.63^{*}$ & $0.78^{* *}$ & 1 \\
\hline
\end{tabular}

Note: $*$ and $* *$ significant at $P \leq 0.05$ or $P \leq 0.01$ respectively. TFC- Total flavonoids compounds, TPC-Total phenolics compounds, Anti= Antioxidant.

In this study polyphenolics (TFC and TPC) concentration in vegetable amaranth related negatively with plant growth (shoot and root fresh weight) with correlation coefficient $r=-0.75$ and -0.85 respectively. As expected antioxidative activity of the amaranth extracts had a significant positive relationship with TFC and TPC which implies a higher possibility that DPPH antioxidative capacity is as a result of higher accumulation of flavonoids and phenolics.

\section{DISCUSSION}

\section{Plant height}

Depression in shoot height agrees with previous work by Borgognone et al. (2013) who observed that plant height was sharply decreased when $\mathrm{NH}_{4}{ }^{+}$was the dominant $\mathrm{N}$ source. The restriction in shoot height for the plants supplied with sole ammonium compared to sole nitrate and mixed form (ammonium nitrate) may probably be related to decline in cell number and cell size, which is manifested by impaired root- to- shoot translocation of cytokinins as indicated by (Walch-Liu et al. 2000) on tobacco. Working with tomatoes Rahayu et al. (2005) reported superiority among nitrate treated plants as compared to ammonium treated plants which were even inferior to ammonium-nitrate- $\mathrm{N}$ plants. Nitrate $\mathrm{N}$ was associated with induction of phytohormonal cascade transduction from root to shoot, leading to expansive leaf growth.

This is in concurrence with findings of Lobit et al. (2006), who found that a $49 \%$ reduction in the shoot length under dominant $\mathrm{NH}_{4}^{+}$nutrition. These results were also in agreement with the findings of GweyiOnyango et al. (2009) who observed a higher relative growth rate under nitrate even with lower concentrations as compared to ammonium.

\section{Total flavonoids and phenolics}

The current study revealed up-regulated build-up of TFC and TPC that when no N form (control) was supplied to the amaranth plants (Table 1). This is in concurrent with results of other workers (Kováčik \& Bačkor 2007, Ibrahim et al. 2011) which show that the accumulation of polyphenolic components in plant tissues is often enhanced under conditions of restricted nitrogen nutrition. Salahas et al. (2011) observed that Ndeficiency stimulated biosynthesis of secondary plant metabolites, such as total phenolics and betacyanins in red beet. Previous findings by Argyropoulou et al. (2015) further revealed that total phenolics concentration significantly increased in N-starved plants, indicating that biosynthesis of secondary plant metabolites is stimulated by nitrogen deficiency, and this is in agreement with the report of Scheible et al. (2004). Lower levels of phenolic and flavonoid compounds in plants grown under high $\mathrm{N}$ supply have been reported for apple trees (Leser \& Treutter 2005). Ammonium-N source was superior in poly-phenolic accumulation compared to other sources. Application of plants with sole ammonium source leads to acidification of rhizosphere (Sabir et al. 2013), which associated with poor plant growth (Gweyi-Onyango et al. 2009). This in turn induces plant defense mechanisms by increased poly-phenolic accumulation (Caldwell et al. 2003) as defense mechanism against nutritional stress. This may be supported by carbon nutrient balance (CNB) hypothesis which anticipates 
that the accumulation of excess carbon in response to nutrient stress leads to the increased production of carbonbased secondary metabolites (CBSM) and their precursors (Yongke et al. 2005). Ammonium nutrition stimulates build-up of high levels of polyamines (Chen et al. 2011, Gill \& Tuteja 2010), which act as precursors of secondary metabolites biosynthesis (Smith 1990). Increased carbon skeletons for ammonium assimilation, might have stimulated shikimic acid pathway activities which in turn could have enhanced the production of plant secondary metabolites (Fan et al. 1998) under sole ammonium treatment. Reduction in sink size to some extend reduces translocation of carbohydrates to other plant parts (Reddy et al. 1996.) and extra carbohydrates might be channeled towards secondary metabolism (Tognetti \&Johnson 1999).

\section{DPPH Anti-oxidant Activity}

Similar to the TFC and TPC accumulation plants supplied with $\mathrm{NH}_{4}{ }^{+}-\mathrm{N}$ exhibited superior scavenging capacity unlike other $\left(\mathrm{NO}_{3}{ }^{-}\right.$and $\mathrm{NH}_{4}{ }^{+} / \mathrm{NO}_{3}{ }^{-}$mixture). Maisarah et al. (2013) observed that phytochemicals such as flavonoids and phenolics constitute a major group of compounds that act as primary antioxidants. Plants exposed to high $\mathrm{NH}_{4}{ }^{+}$concentration as $\mathrm{N}$ source accumulate low molecular osmolytes among them polyamines (Claussen et al. 2006) which enhances the plants tolerance to stresses (Tassoni et al. 2008, Yamaguchi et al. 2007). Moreover polyamines to some extent are involved in detoxification of nitrogen stress acting as nitrogen reservoirs, and free radical scavengers maintaining the integrity of membranes, consequently protecting cells from nitrogen toxicity (Chen et al. 2011). Flavonoids have been reported to possess strong antioxidant activity, indicated by their ability to chelate metals, scavenge singlet oxygen radicals and inhibit oxidation of low density lipoprotein in vitro studies (Kandaswami \& Middleton 1994). Anthocyanins; which are flavonoids (Kumar \& Pandey 2013) lower the accumulation of ROS in vivo under oxidative stress (Nakabayashi et al. 2014). Previous work has been done to support total phenols as effective antioxidants or free radical scavengers (Ogembo 2015, Okello 2015) in leafy vegetables.

\section{Relationship between plant growth and TFC and TPC concentration}

Pearson correlation indicated a strong negative relationship between plant height and TFC and TPC which is in line with the findings of (Ogembo 2015, Sousa et al. 2008) who demonstrated higher levels of total phenolics were accompanied by lower plant growth in Solanum and Brassica species. Phenolics and flavanoids (quarcetin) concentrations increase was observed under inhibited plant growth in Amaranthus hypochondriacus (Onyango et al. 2012). High level of poly-phenolic compounds may be associated with nutritional-induced stress under the sole ammonium and no $-\mathrm{N}$ form due to resource allocation trade-off between plant growth and defense for survival, therefore suppressed plant growth. This is in parallel with results of Donaldson et al. (2006) who reported that nutrient limitation decreased growth, leaf mass ratio, and photosynthesis but augmented leaf condensed tannin concentrations. Negative relationship between growth and condensed tannins indicated an additional indirect cost of allocation to secondary metabolites (Donaldson et al. 2006).

\section{CONCLUSION}

Amaranth plants responded differently to different $\mathrm{N}$ forms. Ammonium $\mathrm{N}$ form restricted plant growth which correlated negatively with polyphenols (total flavonids and phenolics) accumulation. Sole $\mathrm{NH}_{4}{ }^{+}$induced stress enhanced total flavonoids, phenolics and natural antioxidants with effective antioxidative capacity; a striking metabolic plasticity observed during plant growth and survival trade-off in vegetable amaranth. Variety AB7 was superior to AB6 both in terms of growth and accumulation of TFC and TPC which are important for health and hence this would be recommended to farmers as well as consumers.

\section{ACKNOWLEDGEMENTS}

We sincerely thank Kenyatta University- Vice Chancellor's research Grant Programme without which this work may not have been completed. We also want to sincerely thank Prof Christof Engels of Humboldt University, Berlin for providing us with Padin ${ }^{\circledR}$ and Prof. Abukutsa-Onyango of JKUAT for the provision of amaranth seeds.

\section{REFERENCES}

Akula R \& Ravishankar GA (2011) Influence of abiotic stress signals on secondary metabolites in plants. Plant Signaling \& Behavior 6(11): 1720-1731.

Altiok E (2010) Recovery of phytochemicals (having antimicrobial and antioxidant characteristics from local 
plant, PhD. Thesis. İzmir Institute of Technology. İzmir, Turkey.

Amabye TG (2015) Evaluation of Physiochemical, Phytochemical, Antioxidant and Antimicrobial Screening Parameters of Amaranthus spinosus Leaves. Natural Products Chemistry Research 4: 199.

Argyropoulou K, Salahas G, Hela D \& Papasavvas A (2015) Impact of nitrogen deficiency on biomass production, morphological and biochemical characteristics of sweet basil (Ocimum basilicum L.) plants, cultivated aeroponically. Agriculture and food 3: 32-42.

Borgognone D, Colla G, Rouphael Y, Cardarelli M, Rea R \& Schwarz D (2013) Effect of nitrogen form and nutrient solution $\mathrm{pH}$ on growth and mineral composition of self-grafted and grafted tomatoes. Scientia Horticulturae 149: 61-69.

Caldwell MM, Ballaré CL, Bornman, JF, Flint SD, Bjorn LO, Teramura AH, Kulandaivelu G \& Tevini M (2003) Terrestrial ecosystems, increased solar ultraviolet radiation and interactions with other climatic change factors. Photochemical and Photobiological Sciences 2: 29-38.

Caretto S, Linsalata V, Colella G, Mita G \& Lattanzio V (2015) Carbon fluxes between primary metabolism and phenolic pathway in plant tissues under stress. International Journal of Molecular Sciences 16(11): 2637826394.

Chen L, Liu QQ, Gai JY, Zhu YL, Yang LF \& Wang C (2011) Effects of nitrogen forms on the growth and polyamine contents in developing seeds of vegetable soybean. Journal of Plant Nutrition 2 (34): 504-521.

Claussen W, Brückner B, Krumbein A \& Lenz F (2006) Long-term response of tomato plants to changing nutrient concentration in the root environment - the role of proline as an indicator of sensory fruit quality. Plant Science 171: 323-331.

Collins AR (2005) Antioxidant Intervention as a Route to Cancer Prevention. European Journal of Cancer 41: 1923-1930.

Donaldson JR, Kruger EL \& Lindroth RL (2006) Competition and resource-mediated tradeoffs between growth and defensive chemistry in trembling aspen (Populus tremuloides). New Phytologist 169(3): 561-570.

Esmaeili A, Tavassoli A \& Ebrahimzadeh MA (2009) Antioxidant activity and free radical scavenging activity of Salvia glutinosa growing in Iran. Pharmacologyonline 2: 109-116.

FanY, Wang Y, Tan R \& Zhang Z (1998) Seasonal and sexual variety of ginko flavonol glycosides in leaves of Gingko biloba L. Journal of Traditional Chinese Medicine 23: 267-269.

Gill SS \& Tuteja N (2010) Polyamines and abiotic stress tolerance in plants. Plant Signal Behavior 5: 26-33.

Glynn C, Herms DA, Orians CM, Hansen RC \& Larsson S (2008) Testing the growth-differentiation balance hypothesis: Dynamic responses of willows to nutrient availability. New Phytology 176: 623-634.

Gweyi-Onyango JP, Neumann G \& Roemheld V (2009) Effects of Different Forms of Nitrogen on Relative Growth Rate and Growth Components of Tomato (Lycopersicon esculentum Mill.). African Journal of Horticultural Sciences 2: 43-55.

Habwe F, Walingo MK, Abukutsa-Onyango MO \& Oluoch MO (2009) Iron content of the formulated East African indigenous vegetable recipes 2009. African Journal of Food Science 3(12): 393-397.

Ibrahim MH, Jaafar HZ, Rahmat A \& Rahman ZA (2011) Effects of Nitrogen Fertilization on Synthesis of Primary and Secondary Metabolites in Three Varieties of Kacip Fatimah (Labisia Pumila Blume). International Journal of Molecular Sciences 12: 5238-5254.

Kandaswami C \& Middleton E (1994) Free radical scavenging and antioxidant activity of plant flavonoids. Free Radicals in Diagnostic Medicine 366: 351-376.

Kovácik J, Klejdus B, Bǎckor M \& Rep̌cák M (2007) Phenylalanine ammonia-lyase activity and phenolic compounds accumulation in nitrogen-deficient Matricaria chamomilla leaf rosettes. Plant Science 172: 393399.

Kováčik J \& Bačkor M (2007) Changes of phenolic metabolism and oxidative status in nitrogen-deficient Matricaria chamomilla plants. Plant Soil 297: 255-265.

Kumar S \& Pandey AK (2013) Chemistry and Biological Activities of Flavonoids: An Overview. The Scientific World Journal 2013: Article ID 162750.

Kwenin WK, Wolli M \& Dzomeku BM (2011). Assessing the nutritional value of some African indigenous green Leafy Vegetables in Ghana. Journal of Animal and Plant Sciences 10(2): 1300-1305.

Leser C \& Treutter D (2005) Effects of nitrogen supply on growth, contents of phenolic compounds and pathogen (scab) resistance of apple trees. Physiology and Plant 123: 49-56. 
Lillo C, Lea US \& Ruoff P (2008) Nutrient depletion as a key factor for manipulating gene expression and product formation in different branches of the flavonoid pathway. Plant Cell Environment 31: 587-601.

Lobit P, López-Pérez L, Cárdenas-Navarro R, Castellanos-Morales VC \& Ruiz-Corro R (2006) Effect of ammonium/nitrate ratio on growth and development of avocado plants under hydroponic conditions. Canadian Journal of Plant Science 87(1): 99-103.

Maisarah AM, Amira NB, Asmah R \& Fauziah O (2013) Antioxidant analysis of different parts of Carica papaya. International Food Research Journal 20(3): 1043-1048.

Mates MJ, Segura J, Alonso F \& Márquez J (2011) Anticancer antioxidant regulatory functions of phytochemicals. Current Medicinal Chemistry 18(15): 2315-2338.

Mavengahama S (2013) The contribution of indigenous vegetables to food security and nutrition within selected sites in South Africa, Ph.D. Thesis. Faculty of AgriSciences, Stellenbosch University, South Africa.

Mervat M, El Far M \& Taie HA (2009) Antioxidant Activities, Total Anthocyanins, Phenolics and Flavonoids Contents of Some Sweet potato Genotypes under Stress of Different Concentrations of Sucrose and Sorbitol. Australian Journal of Basic and Applied Sciences 3(4): 3609-3616.

Mibei EK, Ojijo, NK, Karanja SM \& Kinyua JK (2012) Phytochemical and antioxidant analysis of methanolic extracts of four African indigenous leafy vegetables. Annals Food Science and Technology 13: 37-42.

Nabavi, SM, Ebrahimzadeh MA, Nabavi SF, Hamidinia A, \& Bekhradnia A (2008) Determination of antioxidant activity, phenol and flavonoids content of Parrotia persica Mey. Pharmacologyonline 2: 560567.

Nakabayashi R \& Saito K (2015) Integrated metabolomics for abiotic stress responses in plants. Current Opinion in Plant Biology 24: 10-16.

Nakabayashi R, Yonekura-Sakakibara K, Urano K, Suzuki M, Yamada Y, Nishizawa T, Matsuda F, Kojima M, Sakakibara H, Shinozaki K \& Michael AJ (2014) Enhancement of oxidative and drought tolerance in Arabidopsis by over-accumulation of antioxidant flavonoids. The Plant Journal 77(3): 367-379.

Ogembo JO (2015) Effects of Phosphorus Deficiency on Secondary Metabolites and Distribution of African Nightshade in Siaya and Kisii Counties, Kenya, Master's Thesis. Kenyatta university, Nairobi, Kenya.

Okello OP (2015) Effects of water stress on antioxidant activity and phenolic contents of African nightshades and their distribution in Kisii and Siaya Counties of Kenya, Master's Thesis. Kenyatta University, Nairobi, Kenya.

Olfati JA, Khasmakhi-Sabet SA \& Shabani H (2012) Nutrient Solutions on Yield and Quality of Basil and Cress. International Journal of Vegetables Science 18: 298-304.

Onyango CM, Harbinson J, Imungi JK, Onwonga RN \& Kooten O (2012) Effect of Nitrogen Source, Crop Maturity Stage and Storage Conditions on Phenolics and Oxalate Contents in Vegetable Amaranth (Amaranthus hypochondriacus). Journal of Agricultural Science 4(7): 219-230.

Rahayu YS, Walch-Liu P, Neumann G, Römheld V, von Wirén N \& Bangerth F (2005) Root-derived cytokinins as long-distance signals for NO3-induced stimulation of leaf growth. Journal of Experimental Botany 56(414): 1143-1152.

Reddy AR, Reddy KR, Padjung R \& Hodges HF (1996) Nitrogen nutrition and photosynthesis in leaves of pima cotton. Journal Plant Nutrition 19: 755-790.

Sabir M, Hanafi MM, Malik MT, Aziz T, Zia-ur-Rehman M, Ahmad HR, Hakeem KR \& Shahid M (2013) Differential effect of nitrogen forms on physiological parameters and micronutrient concentration in maize (Zea mays L.). Australian Journal of Crop Science 7(12): 1836-1842.

Salahas G, Papasavvas A, Giannakopoulos E, Tselios T \& Savvas D (2011) Impact of nitrogen deficiency on biomass production, gas exchange, and betacyanin and total phenol concentrations in red beet (Beta vulgaris L.) plants. European Journal of Horticultural Science 76(5): 194-200.

Scheible WR, Morcuende R, Czechowski T, Fritz C, Osuna D, Palacios-Rojas N, Schindelasch D \& Stitt M (2004) Genome-wide reprogramming of primary and secondary metabolism, protein synthesis, cellular growth processes, and the regulatory infrastructure of arabidopsis in response to nitrogen. Plant Physiology 136: 2483-2499.

Smith TA (1990) Plant polyamines: Metabolism and function. In: Flores HE, Arteca RN \& Shannon JC (eds) Polyamines and Ethylene: Biochemistry, Physiology and Interactions. American Society of Plant Physiologists, New York, USA, pp. 1-23. 
Sousa C, Pereira DM, Pereira JA, Bento A, Rodrigue MA \& Dopico-Garcia S (2008) Multivariate analysis of tronchuda cabbage (Brassica oleracea L. var. costata DC) phenolics: influence of fertilizers. Journal of Agriculture and Food Chemistry 56: 2231-2239.

Sun YD, Lou WR, Liu HC (2014) Effects of different nitrogen forms on the nutritional quality and physiological characteristics of Chinese chive seedlings. Plant, Soil and Environment 60: 216-220.

Tassoni A, Franceschett M \& Bagni N (2008) Polyamines and salt stress response and tolerance in Arabidopsis thaliana flowers. Plant Physiology and Biochemistry 46: 607-613.

Tattini M, Galardi C, Pinelli P, Massai R, Remorini D \& Agati G (2004) Differential accumulation of flavonoids and hydroxycinnamates in leaves of Ligustrum vulgare under excess light and drought stress. New Phytologist 163(3): 547-561.

Tognetti R \& Johnson JD (1999) The effect of elevated atmospheric CO2 concentration and nutrient supply on gas exchange, carbohydrates and foliar phenolic concentration in live oak (Quercus virginiana Mill.) seedlings. Annals of forest science 56(5): 379-389.

Walch-Liu P, Neumann G, Bangerth F, Engels C (2000) Rapid effects of nitrogen form on leaf morphogenesis in tobacco. Journal of Experimental Botany 51(343): 227-237.

Xiang L, Sun K, Lu J, Weng Y, Taoka A, Sakagami Y \& Qi J (2011) Anti-aging effects of phloridzin, an apple polyphenol, on yeast via the SOD and Sir2 genes. Bioscience, biotechnology, and biochemistry 75(5): 854858.

Yamaguchi KY, Takahashi T, Berberich A, Imai T, Takahashi AJ \& Kusano T (2007) Protective role for the polyamine spermine against drought stress in Arabidopsis. Biochemical and Biophysical Research Communications 352: 486-490.

Yongke L, Dan Y \& Yongming H (2005) Effects of UV-B, Nutrient, and Light Availability on Shoot Length and Phenolic Content of Myriophyllum spicatum L.). Journal of Freshwater Ecology 20(1): 59-63.

Zhou YH, Zhang YL, Wang XM, Cui JX, Xia XJ, Shi K \& Yu JQ (2011) Effects of nitrogen form on growth, $\mathrm{CO}_{2}$ assimilation, chlorophyll fluorescence, and photosynthetic electron allocation in cucumber and rice plants. Journal of Zhejiang University Science Biomedical \& Biotechnology 12(2): 126-134. 